\title{
Oxy-fuel combustion of coal and biomass blends
}

\author{
J. Riaza, M.V. Gil, L. Álvarez, C. Pevida, J.J. Pis, F. Rubiera* \\ Instituto Nacional del Carbón, INCAR-CSIC, Apartado 73, 33080 Oviedo, Spain
}

\begin{abstract}
The ignition temperature, burnout and NO emissions of blends of a semi-anthracite and a high-volatile bituminous coal with 10 and $20 \mathrm{wt} . \%$ of olive waste were studied under oxy-fuel combustion conditions in an entrained flow reactor (EFR). The results obtained under several oxy-fuel atmospheres $\left(21 \% \mathrm{O}_{2}-79 \% \mathrm{CO}_{2}, 30 \% \mathrm{O}_{2}-70 \% \mathrm{CO}_{2}\right.$ and $35 \% \mathrm{O}_{2}$ $\left.65 \% \mathrm{CO}_{2}\right)$ were compared with those attained in air. The results indicated that replacing $\mathrm{N}_{2}$ by $\mathrm{CO}_{2}$ in the combustion atmosphere with $21 \%$ of $\mathrm{O}_{2}$ caused an increase in the temperature of ignition and a decrease in the burnout value. When the $\mathrm{O}_{2}$ concentration was increased to 30 and $35 \%$, the temperature of ignition was lower and the burnout value was higher than in air conditions. A significant reduction in ignition temperature and a slight increase in the burnout value was observed after the addition of biomass, this trend becoming more noticeable as the biomass concentration was increased. The emissions of NO during oxy-fuel combustion were lower than under air-firing. However, they remained similar under all the oxy-fuel atmospheres with increasing $\mathrm{O}_{2}$ concentrations. Emissions of NO were significantly reduced by the addition of biomass to the bituminous coal, although this effect was less noticeable in the case of the semianthracite.
\end{abstract}

\footnotetext{
* Corresponding author. Tel.: +34 985118 975; Fax: +34 985297662.

E-mail address: frubiera@incar.csic.es (F. Rubiera)
} 
Keywords: Coal; Biomass; Oxy-fuel combustion; Ignition; Burnout; NO emissions; Entrained flow reactor

\section{Introduction}

The role of coal as an energy source has attracted renewed interest due to the stability of its supply and its relatively low cost, which will probably guarantee its inclusion in the energy mix in the foreseeable future [1]. Until renewable energy sources can reliably produce significant amounts of energy, the immediate energy demand is likely to be met by conventional fossil fuel combustion, such as coal. However, coal combustion produces a large amount of $\mathrm{CO}_{2}$, which is the chief contributor to global climate change. To meet future targets for the reduction of greenhouse gas (GHG) emissions, $\mathrm{CO}_{2}$ must be captured and stored. Several strategies for the reduction and capture of $\mathrm{CO}_{2}$ from large-scale stationary power plants are currently being studied.

The oxy-fuel combustion of coal with recycled flue gas is considered as a promising option to ensure the continued use of coal for electric power production [2-5]. Conventional pf coal-fired boilers use air for combustion and the nitrogen in the air (approximately $79 \%$ by volume) has the effect of diluting the concentration of $\mathrm{CO}_{2}$ in the flue gas, which is present in concentrations of $14-16 \%$ in air-firing conditions. However, during oxy-fuel combustion, fuel is burnt in a mixture of oxygen and recycled flue gas to yield a rich $\mathrm{CO}_{2}(95 \%)$ and water vapour stream, which after purification and compression is ready for sequestration [6]. An important advantage of this technology is that it avoids the formation of thermal $\mathrm{NO}_{x}$ due to the absence of nitrogen gas in the combustion atmosphere, with the result that $\mathrm{NO}_{x}$ emissions are reduced. The amount of $\mathrm{NO}_{x}$ released also decreases because the $\mathrm{NO}_{x}$ in the recycled flue gas decomposes as it 
comes into contact with the flame-generated hydrocarbons and the reducing atmosphere near the flame, a mechanism to which Scheffknecht et al. [7] attach considerable importance.

In addition, the oxy-combustion of coal makes it possible to capture and sequester carbon using technology already available in conventional pulverized coal boilers, and to capitalize on the enormous quantities of money invested in existing boilers. What is more, oxy-fuel recycle combustion requires only a slight modification of the existing pulverized coal combustion technology that has already demonstrated its reliability and won widespread industrial acceptance [5].

The combustion of coal in the $\mathrm{O}_{2} / \mathrm{CO}_{2}$ atmosphere of an oxy-coal combustion boiler may be expected to be different to that of an $\mathrm{O}_{2} / \mathrm{N}_{2}$ atmosphere of a conventional coalair combustion boiler, because the $\mathrm{CO}_{2}$ gas is denser and has a higher specific heat capacity than $\mathrm{N}_{2}$ and because coal may be gasified by the $\mathrm{CO}_{2}$. Consequently, the replacement of $\mathrm{N}_{2}$ by $\mathrm{CO}_{2}$ will decrease the speed of propagation and stability of the flame and gas temperature, while increasing the unburned carbon content. It is for this reason that a high oxygen concentration in an oxy-fuel combustion atmosphere (up to approximately $30 \%$ ) is generally used in order to match the combustion performance achieved in air in relation to flame temperature, ignition time, heat transfer, gas temperature profile and char burnout.

On the other hand, biomass is a renewable fuel which can be used to reduce $\mathrm{CO}_{2}$ emissions. This source of energy is considered carbon neutral because the carbon dioxide released during its combustion is recycled as an integral part of the carbon cycle. The co-firing of biomass with coal is an environmentally friendly method of coal utilization since it reduces harmful emissions and provides an alternative to landfilling 
[8]. One of the main advantages of co-firing biomass and coal is its relatively easy and cheap application in existing pulverized coal power plants, that requires only minor modifications compared to the costly construction of new biomass-only fired power plants [9]. The combination of oxy-fuel combustion with biomass could afford a method of disposal for $\mathrm{CO}_{2}$ that has only partially been studied. Preliminary works have been carried out employing thermogravimetric analysis $[8,10]$ and an entrained flow reactor [11] with the aim of studying the cofiring of coal and biomass under oxy-fuel conditions, but more research is required in order to introduce this practice at industrial scale.

In this work, a biomass derived from the olive oil production process, olive waste (OW), was utilized. It is the part of the olive that remains after the olive oil has been milled and extracted. The objective was to study the co-firing of coal with this biomass under oxy-fuel combustion conditions in an entrained flow reactor. Air conditions were used for comparison. The ignition temperature, burnout and NO emissions from various coal/biomass blends under air and oxy-fuel environments were determined and, in this way, the effect of adding biomass upon the oxy-fuel combustion of coal was evaluated.

\section{Materials and methods}

\subsection{Materials}

Two coals of different rank were used in this work: a semi-anthracite from the Hullera Vasco-Leonesa in León (Spain), HVN, and a South African high-volatile bituminous coal from the Aboño power plant in Asturias (Spain), SAB. A biomass, olive waste (OW), was also employed. The coal and biomass samples were ground and sieved to 
obtain a particle size fraction of $75-150 \mu \mathrm{m}$. The proximate and ultimate analyses together with the higher heating values of the samples are presented in Table 1.

\subsection{Experimental device and procedure}

The ignition and oxy-fuel combustion characteristics of the coals and coal/biomass blends at high heating rates and short residence times were studied in an entrained flow reactor (EFR), which has been described in detail elsewhere [12,13]. Briefly, the reactor has a reaction zone of length $1400 \mathrm{~mm}$ and internal diameter $40 \mathrm{~mm}$ which is electrically heated and is capable of reaching a maximum temperature of $1100{ }^{\circ} \mathrm{C}$. Fuel samples are fed in from a hopper through an air-cooled injector to ensure that the temperature does not exceed $100{ }^{\circ} \mathrm{C}$ before entering the reaction zone and the mass flow is controlled by means of a mechanical feeding system. The gases are preheated to the oven temperature before being introduced into the reactor through flow straighteners. The flow rates of $\mathrm{N}_{2}, \mathrm{CO}_{2}$ and $\mathrm{O}_{2}$ from the gas cylinders are controlled by mass flow controllers. A water-cooled collecting probe is inserted into the reaction chamber from below. Nitrogen is introduced at the top of this probe to quench the reaction products. Particles are removed by means of a cyclone and a filter, and the exhaust gases are monitored using a battery of analyzers $\left(\mathrm{O}_{2}, \mathrm{CO}_{2}, \mathrm{CO}\right.$, $\mathrm{NO}$ and $\left.\mathrm{SO}_{2}\right)$.

During the ignition tests carried out in the present study, the reactor was heated at $15^{\circ} \mathrm{C} \mathrm{min}{ }^{-1}$ from 400 to $800{ }^{\circ} \mathrm{C}$. The gas flow used in the tests ensured a particle residence time of $2.5 \mathrm{~s}$ at $500{ }^{\circ} \mathrm{C}$, and excess oxygen (defined as the $\mathrm{O}_{2}$ supplied in excess of that required for the stoichiometric combustion of coal) was set at a value of $25 \%$. The criterion for determining the ignition temperature was based on the first derivative temperature curves of the gases produced. The ignition temperature was 
taken as the temperature at which the first derivative temperature curve, normalized by the maximum derivative value, reached a value of $10 \%[14]$.

On the other hand, the combustion tests were carried out at a reaction temperature of $1000{ }^{\circ} \mathrm{C}$ employing a particle residence time of $2.5 \mathrm{~s}$. In order to check the constant gas temperature over the reactor height, a temperature profile along the reactor was measured with a fine wire type $\mathrm{K}$ thermocouple, while the gas was flowing, and it was found to be $1000 \pm 10^{\circ} \mathrm{C}$. Burnout is defined as the loss of mass of a fuel during its combustion and is expressed as the ratio of mass loss during combustion to the total mass in the input coal. Fuel mass loss during the experiments was determined by the ash tracer method. The experimental errors in the burnout and NO measurements were 4 and $5 \%$ respectively.

Four binary mixtures of $\mathrm{O}_{2} / \mathrm{N}_{2}$ and $\mathrm{O}_{2} / \mathrm{CO}_{2}$ were employed to study the combustion behaviour of the coals and coal/biomass blends. Thus, for the ignition and combustion tests, air $\left(21 \% \mathrm{O}_{2}-79 \% \mathrm{~N}_{2}\right)$ was taken as reference and three binary mixtures of $\mathrm{O}_{2}$ and $\mathrm{CO}_{2}$ were compared: $21 \% \mathrm{O}_{2}-79 \% \mathrm{CO}_{2}, 30 \% \mathrm{O}_{2}-70 \% \mathrm{CO}_{2}$ and $35 \% \mathrm{O}_{2}-65 \% \mathrm{CO}_{2}$. The addition of 10 and $20 \mathrm{wt} . \%$ of olive waste to the coals was evaluated for all of the air and the oxy-fuel combustion atmospheres, in order to study the effect of adding biomass on the ignition temperature, burnout value and NO emissions.

\section{Results and discussion}

\subsection{Ignition temperature}

The ignition temperature of the semianthracite $\mathrm{HVN}$ and the bituminous coal SAB, as well as their blends with OW, under the different atmospheres studied is presented in Fig. 1. Both coals showed the same behaviour in relation to the combustion atmosphere. 
However, the ignition of the HVN coal took place at much higher temperatures than that of the SAB coal in all of the atmospheres studied, in accordance with its rank (Table 1). The reactivity of the high-volatile bituminous coal, $\mathrm{SAB}$, is greater than that of the semi-anthracite, HVN, as a result of which one would expect heat to be released earlier and the ignition temperatures to be reduced.

The behaviour of the coal/biomass blends under the oxy-fuel combustion atmospheres was similar to that of the individual coals. Thus, when $\mathrm{N}_{2}\left(21 \% \mathrm{O}_{2}-79 \% \mathrm{~N}_{2}\right)$ was replaced by $\mathrm{CO}_{2}\left(21 \% \mathrm{O}_{2}-79 \% \mathrm{CO}_{2}\right)$, the ignition temperature increased (Fig. 1). This may be attributed to the higher specific molar heat of $\mathrm{CO}_{2}$ compared to $\mathrm{N}_{2}$. Before ignition, the fuel particles are heated up by the ambient environment until the combustion occurs. The radiant heat from the particles then causes an increase in the temperature of the gas. Because of the higher specific molar heat of $\mathrm{CO}_{2}$, more ambient heat is needed to increase the temperature under an oxy-fuel combustion atmosphere. This results in a comparatively lower gas temperature and, therefore, a reduction in the fuel particle temperature during oxy-fuel combustion in comparison to combustion in air at the same oxygen concentration [13]. This should lead to a delay in the ignition of volatiles and char under the $21 \% \mathrm{O}_{2}-79 \% \mathrm{CO}_{2}$ atmosphere, as pointed out by Liu et al. [15] and Molina and Shaddix [16]. Liu et al. [17] observed a longer ignition delay under the $\mathrm{CO}_{2}$ atmosphere than under $\mathrm{N}_{2}$ in an entrained flow reactor, which they attributed to the higher volumetric heat capacity of $\mathrm{CO}_{2}$ inhibiting the local thermal runaway. The reduced diffusivity of oxygen in $\mathrm{CO}_{2}$ may also have contributed to the delay in ignition. When the oxygen concentration was increased $\left(30 \% \mathrm{O}_{2}-70 \% \mathrm{CO}_{2}\right.$ and $\left.35 \% \mathrm{O}_{2}-65 \% \mathrm{CO}_{2}\right)$, the ignition temperature decreased to below that of the air conditions, both in the case of the coals and the coal/biomass blends (Fig. 1). If the $\mathrm{O}_{2}$ concentration was increased, 
the mass flux of $\mathrm{O}_{2}$ to the fuel surface particles, the rate of devolatilization and the oxidation rate of the volatiles will also increase. This will shorten the fuel particle autoignition time considerably [18]. Molina and Shaddix [16] observed in single particle experiments that the particle ignition and devolatilization properties in a atmosphere of $30 \% \mathrm{O}_{2}$ in $\mathrm{CO}_{2}$ were similar to those of air.

Information on the effect of high levels of $\mathrm{CO}_{2}$ on the ignition of coal/biomass particles is important both for understanding how to prepare existing burners that operate in air for operating in $\mathrm{O}_{2} / \mathrm{CO}_{2}$ mixtures, and for the CFD modelling of the performance of pulverized coal burners in $\mathrm{O}_{2} / \mathrm{CO}_{2}$ systems [7].

From Fig. 1 it can also be seen that the addition of olive waste, OW, caused a significant reduction in the ignition temperatures of both coals in all the atmospheres studied. This decrease became more pronounced as the biomass concentration in the blend was increased due to the fact that because biomass is a highly reactive fuel and has high volatile matter content (Table 1), it will react faster and improve the ignition behaviour of the coal. As the percentage of biomass is increased, more heat will be released earlier leading to a greater reduction in the ignition temperature of the blend. Arias et al. [11] observed a substantial reduction in the ignition temperature of coal/biomass blends in air but only a small decrease under oxy-fuel combustion atmospheres. They explained this because biomass has a lower heating value than coal, and so less heat is generated during its oxidation in the ignition process, and $\mathrm{CO}_{2}$ has a specific heat higher than $\mathrm{N}_{2}$. Thus, when $\mathrm{CO}_{2}$ is the major component in the surrounding gases, the heat released by the biomass present in the blend generates a small increase in the temperature of the gases and so the ignition properties of coal are less affected. However, in the present work, a reduction in the ignition temperature of 
coal/biomass blends occurred both in the air and oxy-fuel atmospheres, in agreement with the results of Gil et al. [10], who from a previous thermogravimetric analysis, observed that the addition of olive waste to the HVN coal caused a decrease in the combustion and oxy-fuel combustion temperatures.

Decreases in the ignition temperature of $75-54^{\circ} \mathrm{C}$ and $139-111^{\circ} \mathrm{C}$ were achieved when coal HVN was blended with 10 and $20 \mathrm{wt} . \%$ of OW, respectively. When the SAB coal was blended with 10 and 20 wt.\% of $\mathrm{OW}$, reductions of $43-33^{\circ} \mathrm{C}$ and $87-73{ }^{\circ} \mathrm{C}$, respectively, were achieved. These differences can be attributed to the different reactivities of these coals resulting in much lower ignition temperatures in the case of the SAB coal. The ignition temperature of coal SAB was therefore less affected by the addition of biomass than that of the HVN coal. These results suggest that the effect of the addition of biomass on the ignition temperature of coal is more significant in high rank coals, which have much lower reactivity values than the biomass.

\subsection{Burnout}

Coals HVN and SAB and their blends with biomass were burned at different levels of excess oxygen for each atmosphere studied. The fuel equivalence ratio, defined as the ratio between the fuel mass flow rate and the stoichiometric value, was used to determine the excess oxygen during combustion.

The burnout values of HVN and SAB, and their blends with olive waste (OW), are shown in Figs. 2 and 3, respectively. It can be seen that the burnout value decreased as the fuel equivalence ratio increased due to less oxygen being available at higher fuel equivalence ratio values. For coal HVN and its blends with OW, the burnout showed an almost linear dependence on the fuel equivalence ratio in both the air and oxy-fuel 
conditions (Fig. 2). Even at low values of fuel equivalence ratio (high excess oxygen), the samples showed low burnout values, reflecting the lower reactivity of this high rank coal. However, at low fuel equivalence ratio values (high oxygen excess), the burnout curves of $\mathrm{SAB}$ and its blends with biomass showed an asymptotic approach towards values close to $100 \%$ (Fig. 3) due to the high reactivity of this coal.

In order to facilitate a comparison of the behaviour of these coals and their blends with biomass under air and oxy-fuel atmospheres, the burnout values were interpolated at a fuel equivalence ratio of 0.8 using the curves shown in Figs. 2 and 3. The results for both, HVN and SAB, are presented in Fig. 4a and Fig. 4b, respectively. The burnout behaviour of the coal/biomass blends under the oxy-fuel combustion atmospheres in relation to the air atmosphere was similar to that of the individual coals.

For both coals and their blends with biomass (Fig. 4), the burnout value obtained under the $21 \% \mathrm{O}_{2}-79 \% \mathrm{CO}_{2}$ atmosphere was lower than that reached under $21 \% \mathrm{O}_{2}-79 \% \mathrm{~N}_{2}$ conditions. Liu et al. [15] observed that, when air was replaced by $21 \% \mathrm{O}_{2}-79 \% \mathrm{CO}_{2}$, the gas temperatures dropped significantly. Due to the higher specific molar heat of $\mathrm{CO}_{2}$, the heating capacity of the surrounding gases will be higher, which in turn will lead to lower flame and gas temperatures under this atmosphere. According to Zhang et al. [18], the specific heat capacity of the diluent gas is one of the principal factors affecting char surface temperature for any given fraction of $\mathrm{O}_{2}$. Therefore, particle temperature in a $21 \% \mathrm{O}_{2}-79 \% \mathrm{CO}_{2}$ atmosphere can be expected to be lower, which will cause the combustion rate of the char and the fuel burnout value to fall [11]. In addition, Li et al. [19] attributed the different coal combustion behaviours under both atmospheres in a drop tube furnace to the lower diffusivity of $\mathrm{O}_{2}$ in $\mathrm{CO}_{2}$ than in $\mathrm{N}_{2}$, impeding the 
transport of $\mathrm{O}_{2}$ to the surface of the particles and reducing the combustion rate of the volatile matter and char in oxy-fuel conditions.

Under the $30 \% \mathrm{O}_{2}-70 \% \mathrm{CO}_{2}$ and $35 \% \mathrm{O}_{2}-65 \% \mathrm{CO}_{2}$ atmospheres, the burnout of the $\mathrm{HVN}$ and SAB coals and their blends with biomass was higher than in air (Fig. 4), which is explained because the higher oxygen concentration caused an increase in the char combustion rate, together with a decrease in the ignition temperature. The lower ignition temperature means a higher combustion time, which will lead to reach higher burnout values. Though the gas temperature increases only slightly when the $\mathrm{O}_{2}$ fraction in bulk gas is increased, it is likely that the increase in the mass flux rate of $\mathrm{O}_{2}$ to the particle surface at higher $\mathrm{O}_{2}$ concentrations promotes the consumption rate of the volatiles [20] and provides extra heat feedback to the particle, enhancing devolatilization, ignition and combustion.

It can be seen that under the air and the three oxy-fuel combustion atmospheres studied, the addition of olive waste, OW, caused an increase in the burnout value of both coals, this increase becoming more pronounced as the biomass concentration increased. Smart et al. [21] also observed an improvement in burnout by co-firing coal and biomass (shea meal and sawdust) under both oxy-fuel and air firing conditions.

Previous studies on the co-combustion of coal/biomass blends have also shown that the addition of biomass to coal can improve the burnout efficiency of coal to a certain degree [22]. Since biomass has a higher volatile matter content and a lower ash content, devolatilization and gaseous phase combustion can acquire more importance than in the case of the combustion of an individual coal. Munir et al. [23] studied shea meal and cotton stalk as potential fuels for co-combustion with coal and also concluded that the 
co-combustion of biomass with coal is beneficial from the point of view of burnout due to the greater reactivity of biomass char.

If the reactivities of two fuels which are burned as a blend are different, there will be differences in their combustion, as the more reactive fuel will react faster, thereby reducing oxygen concentration and increasing the temperature at the top of the reaction chamber. Any improvement in the burnout of the less reactive component will depend on the oxygen and temperature profiles in the reactor [11]. In this work, olive waste, OW, was more reactive than coals HVN and SAB and so the burnout of the blends was improved. This indicates that the coals were not negatively affected by the modification of the oxygen and temperature profiles due to the biomass combustion, i.e., the availability of oxygen was not restricted during the combustion of the blend.

The improvement in burnout after the addition of biomass, especially in the $20 \mathrm{wt} . \%$ biomass blends, was more noticeable in the case of HVN than SAB. This may be due to the fact that the individual SAB coal had already reached a high burnout degree before blending, so there was less margin for improvement by adding olive waste to this coal. The addition of $20 \%$ of biomass was therefore less effective.

From the results obtained, it can be concluded that the addition of biomass had a greater effect on the ignition temperature than on the burnout, especially with high biomass concentrations in the blend, all of which underlines the importance of the devolatilization and gaseous phase after the addition of biomass. On the other hand, since biomass has a lower calorific value and higher moisture content than coal, the flame temperature may be reduced and the radiative heat flux impeded if the concentration of biomass in the blend is too high. This would then reduce the oxidation rate as Smart et al. [21] suggested. However, these authors have shown that the positive 
effect of co-firing with biomass on burnout is dependent on the type of biomass and have observed significant improvements in burnout value when biomass with a high reactivity is used.

\subsection{NO emissions}

The NO concentration (mg NO/mg burned fuel) values interpolated at a fuel equivalence ratio of 0.8 for coals $\mathrm{HVN}$ and $\mathrm{SAB}$ and their blends with olive waste (OW) are shown in Fig. 5. For both coals, the NO concentration obtained under the $21 \% \mathrm{O}_{2}-79 \% \mathrm{CO}_{2}$ atmosphere was lower than that achieved under $21 \% \mathrm{O}_{2}-79 \% \mathrm{~N}_{2}$ conditions. The lower NO concentrations in the oxy-fuel combustion atmospheres than in air are partly explained by the suppression of thermal NO formation since there is no nitrogen gas in the combustion atmosphere. However, under the experimental conditions of the present study, this explanation does not seem applicable. Under air conditions, the thermal formation of NO resulting from the reaction between molecular $\mathrm{N}_{2}$ and $\mathrm{O}_{2}$ occurs at high temperatures. In this work however, this route could make only a minor contribution to the formation of $\mathrm{NO}$ due to the temperature used $\left(1000{ }^{\circ} \mathrm{C}\right)$. It would appear, therefore, than the lower NO concentration obtained under the oxy-fuel atmosphere with $21 \%$ of $\mathrm{O}_{2}$ than under air conditions was probably due to the greater NO reduction under oxy-fuel conditions resulting from the chemical reactions of NO with either $\mathrm{CO}$ or with nitrogen species (volatile-N) and hydrocarbon species released during devolatilization. Andersson et al. [24] found that the formation of NO from fuel$\mathrm{N}$ in oxy-fuel combustion was the same as, or slightly higher than, in air-firing conditions, whereas the reduction of NO could be up to $50 \%$ greater in oxy-combustion. In the present experiments therefore the lower NO emissions during oxy-fuel 
combustion than under air-firing must have been due to the increased reduction of NO under the $\mathrm{O}_{2} / \mathrm{CO}_{2}$ atmosphere. Okazaki and Ando [25] also concluded that the reduction of NO to molecular $\mathrm{N}_{2}$ due to chemical reactions in the combustion zone under oxy-fuel conditions was the main reason for the overall decrease in NO concentration. AlMakhadmeh et al. [26] found that the reduction of NO is enhanced during combustion in $\mathrm{O}_{2} / \mathrm{CO}_{2}$ compared to combustion in $\mathrm{O}_{2} / \mathrm{N}_{2}$. Liu et al. [15] found that the higher $\mathrm{CO}$ concentrations inside the oxy-fuel combustion zone and within the vicinity of the combustion particles resulted in a further reduction of NO. Gasification of the char with $\mathrm{CO}_{2}$ may have contributed to an increase in the production of $\mathrm{CO}$ during oxy-fuel combustion. Furthermore, the recent results of experimental investigation on $\mathrm{NO}_{x}$ formation during the oxy-fuel combustion of pulverized coal published by Shaddix and Molina [5] and Sun et al. [27] lead to the conclusion that fuel-N conversion to NO in $\mathrm{O}_{2} / \mathrm{CO}_{2}$ is lower than in $\mathrm{O}_{2} / \mathrm{N}_{2}$, and that this may contribute to a lower NO concentration. Yoshiie et al. [28] found that the NO emissions and conversions of fuel nitrogen to NO under oxy-fuel combustion conditions were lower than that under air combustion conditions without adding NO in the fed atmosphere. Also, Jiang et al. [29] shown lower NO concentrations under oxy-fuel combustion atmospheres than in air without gas recirculation.

In the $30 \% \mathrm{O}_{2}-70 \% \mathrm{CO}_{2}$ and $35 \% \mathrm{O}_{2}-65 \% \mathrm{CO}_{2}$ atmospheres, the $\mathrm{NO}$ concentrations were similar to that of the oxy-fuel atmosphere containing $21 \%$ of $\mathrm{O}_{2}$ (Fig. 5). In none of the oxy-fuel atmospheres did the NO concentration reach that of air. Only small differences in NO concentrations under the oxy-fuel atmospheres with increasing $\mathrm{O}_{2}$ concentrations were found in the present study. Andersson et al. [25] found that NO emissions per unit of fuel energy supplied fell under oxy-fuel combustion with $25 \%$ of $\mathrm{O}_{2}$ compared to air 
firing conditions, but they found only small differences in the reduction of NO for different $\mathrm{O}_{2}$ concentrations $(25,27$ and $29 \%)$ in oxy-fuel atmospheres.

For the SAB coal (Fig. 5b), it can be seen that the NO concentration in air and under oxy-fuel atmospheres decreased after the addition of biomass, this decrease becoming greater as the biomass concentration was increased. For the HVN coal (Fig. 5a), the same tendency was observed, but the decrease in NO concentration values was smaller. The effect of co-firing biomass with pulverised coal on $\mathrm{NO}_{x}$ formation is highly complex and is dependent as much on the relative reactivities of the fuels as on the inherent nitrogen contents of the individual fuels $[23,30]$.

Since the HVN coal and the biomass used in the present work showed similar values of nitrogen content (Table 1), the lower NO emissions during co-firing cannot be explained by the dilution of $\mathrm{N}$ in the mixed fuel because of the lower nitrogen content in the biomass. However, in the case of the SAB coal the dilution of $\mathrm{N}$ may have had an effect since the nitrogen content of SAB was slightly higher than that of the biomass OW (Table 1), which could have increased the differences in NO emissions after the addition of the biomass.

Skeen et al. [31] studied the NO emissions during coal/biomass combustion under airfired and oxy-fuel conditions in a laboratory-scale combustor and found that NO emissions were reduced with the addition of biomass under air firing conditions but not under oxy-fuel conditions.

A reasonable explanation for the decrease in NO emissions after the addition of biomass has been provided by Liu et al. [32] in their study on conventional co-combustion of coal and biomass. These authors believe that lower $\mathrm{NO}_{x}$ emissions may occur during cocombustion than with individual coals because most of the biomass is released as 
volatiles (about $75 \%$ at temperatures above $800{ }^{\circ} \mathrm{C}$ ) and the fuel- $\mathrm{N}$ in the biomass is predominantly liberated as $\mathrm{NH}_{3}$ which may on the one hand form $\mathrm{NO}_{x}$, but also act as a reducing agent in further reactions with $\mathrm{NO}_{x}$ to form $\mathrm{N}_{2}$. Since most of fuel-N in coal is retained in the char and is then oxidised to $\mathrm{NO}_{x}$, the $\mathrm{NH}_{3}$ originating from the biomass may lead to the reduction of $\mathrm{NO}_{x}$, since the high amount of released volatile matter from the biomass combustion produces a fuel-rich condition in the atmosphere which would favour the reduction of NO [33]. Akpulat et al. [34] studied the co-combustion of coal and olive cake in a fluidized bed combustor and they attribute the decrease in $\mathrm{NO}_{x}$ concentrations to the percentage of olive cake in the fuel being increased by the higher amount of volatile matter evolved from the olive cake, and to the generation of high levels of hydrocarbon radicals and $\mathrm{CO}$ formation (reducing atmosphere) in the freeboard region.

In the case of the SAB coal, its higher volatile matter content may have contributed to the creation of a reducing atmosphere that favored the consumption of $\mathrm{NO}$, which would explain why the reduction in the concentration of NO was greater than in the HVN coal. In general, it seems that the effect of the addition of biomass on the NO emissions from coal is more noticeable in low rank coals, which have a higher volatile matter content.

\section{Conclusions}

The ignition temperature and burnout of a semi-anthracite and a high-volatile bituminous coal and their blends with biomass (olive waste) were studied under oxyfuel combustion conditions in an entrained flow reactor (EFR). As in the case of the individual coals, the ignition temperature of the coal/biomass blends was higher under a 
$21 \% \mathrm{O}_{2}-79 \% \mathrm{CO}_{2}$ atmosphere than in air conditions, whereas the burnout was lower due to the higher specific molar heat of $\mathrm{CO}_{2}$ compared to $\mathrm{N}_{2}$ and the lower diffusivity of $\mathrm{O}_{2}$ in $\mathrm{CO}_{2}$ than in $\mathrm{N}_{2}$. However, when the $\mathrm{O}_{2}$ concentration was increased to 30 and $35 \%$ in the oxy-fuel combustion atmosphere, the ignition temperature was lower than in air, while the burnout value was greater than that achieved under air-firing. This was due to an increase in the mass flux of $\mathrm{O}_{2}$ to the surface of the coal particles. The addition of biomass to the coal improved the ignition temperatures and the burnout values in both the air and oxy-fuel combustion atmospheres under the experimental conditions of this study, reflecting the higher volatile content and reactivity of the biomass. The addition of biomass had a more pronounced effect on the ignition temperature than on burnout. NO emissions were lower during oxy-fuel combustion than in air-firing, but only small differences in the reduction of $\mathrm{NO}$ in relation to the $\mathrm{O}_{2}$ concentration in the three oxyfuel combustion atmospheres were observed. The addition of biomass significantly reduced the NO emissions from the bituminous coal, both under air and under oxy-fuel atmospheres, this decrease being proportional to the concentration of biomass. However the reduction of NO emissions was less noticeable in the case of the semi-anthracite.

\section{Acknowledgements}

This work was carried out with financial support from the Spanish MICINN (Project PS-120000-2005-2) co-financed by the European Regional Development Fund. M.V.G. and L.A. acknowledge funding from the CSIC JAE-Doc and CSIC JAE-Pre programs, respectively, co-financed by the European Social Fund. J.R. acknowledges funding from the Government of the Principado de Asturias (Severo Ochoa program). 


\section{References}

[1] Buhre BJP, Elliott LK, Sheng CD, Gupta RP, Wall TF. Oxy-fuel combustion technology for coal-fired power generation. Prog Energy Combust Sci 2005;31:283-307.

[2] Hong J, Chaudhry G, Brisson JG, Field R, Gazzino Marco, Ghoniem AF. Analysis of oxy-fuel combustion power cycle utilizing a pressurized coal combustor. Energy 2009;34:1332-40.

[3] Liszka M, Ziębik A. Coal-fired oxy-fuel power unit - Process and system analysis. Energy 2010;35:943-51.

[4] Pak PS, Lee YD, Ahn KY. Characteristics and economic evaluation of a power plant applying oxy-fuel combustion to increase power output and decrease $\mathrm{CO}_{2}$ emission. Energy 2010;35:3230-8.

[5] Shaddix CR, Molina A. Fundamental investigation of $\mathrm{NO}_{x}$ formation during oxyfuel combustion of pulverized coal. Proc Combust Inst 2011;33:1723-30.

[6] Wall T, Liu Y, Spero C, Elliott L, Khare S, Rathnam R et al. An overview on oxyfuel coal combustion-State of the art research and technology development. Chem Eng Res Des 2009;87:1003-16.

[7] Scheffknecht G, Al-Makhadmeh L, Schnell U, Maier J. Oxy-fuel coal combustion-A review of the current stat-of-the-art. Int J Greenhouse Gas Control 2011;5S:S16S35.

[8] Yuzbasi NS, Selçuk N. Air and oxy-fuel combustion characteristics of biomass/lignite blends in TGA-FTIR. Fuel Process Technol 2011;92:1101-8.

[9] Syed AU, Simms NJ, Oakey JE. Fireside corrosion of superheaters: Effects of air and oxy-firing of coal and biomass. Fuel 2011, doi:10.1016/j.fuel.2011.03.010.

[10] Gil MV, Riaza J, Álvarez L, Pevida C, Pis JJ, Rubiera F. A study of oxy-coal combustión with steam addition and biomass blending by thermogravimetric análisis. J Therm Anal Calorim 2011, doi:10.1007/s10973-011-1342-y.

[11] Arias B, Pevida C, Rubiera F, Pis JJ. Effect of biomass blending on coal ignition and burnout during oxy-fuel combustion. Fuel 2008;87:2753-9.

[12] Álvarez L, Riaza J, Gil MV, Pevida C, Pis JJ, Rubiera F. NO emissions in oxy-coal combustion with the addition of steam in an entrained flow reactor. Greenhouse Gas Sci Technol 2011;1:180-90.

[13] Riaza J, Álvarez L, Gil MV, Pevida C, Pis JJ, Rubiera F. Effect of oxy-fuel combustion with steam addition on coal ignition and burnout in an entrained flow reactor. Energy 2011;36:5314-9.

[14] Faúndez J, Arenillas A, Rubiera F, García X, Gordon AL, Pis JJ. Ignition behaviour of different rank coals in an entrained flow reactor. Fuel 2005;84:21727.

[15] Liu H, Zailani R, Gibbs BM. Comparisons of pulverized coal combustion in air and in mixtures of $\mathrm{O}_{2} / \mathrm{CO}_{2}$. Fuel 2005;84:833-40.

[16] Molina A, Shaddix CR. Ignition and devolatilization of pulverized bituminous coal particles during oxygen/carbon dioxide coal combustion. Proc Combust Inst 2007;31:1905-12.

[17] Liu Y, Geier M, Molina A, Shaddix CR. Pulverized coal stream ignition delay under convencional and oxy-fuel combustión conditions. Int J Greenhouse Gas Control 2011;5S:S36-S46. 
[18] Zhang L, Binner E, Qiao Y, Li C-Z. In situ diagnostics of Victorian brown coal combustion in $\mathrm{O}_{2} / \mathrm{N}_{2}$ and $\mathrm{O}_{2} / \mathrm{CO}_{2}$ mixtures in drop-tube furnace. Fuel 2010;89:2703-12.

[19] Li X, Rathnam RK, Yu J, Wang Q, Wall T, Meesri C. Pyrolysis and combustion characteristics of an Indonisian low-rank coal under $\mathrm{O}_{2} / \mathrm{N}_{2}$ and $\mathrm{O}_{2} / \mathrm{CO}_{2}$ conditions. Energy Fuels 2010;24:160-4.

[20] Shaddix CR, Molina A. Particle imaging of ignition and devolatilization of pulverized coal during oxy-fuel combustion. Proc Combust Inst 2009;32:2091-8.

[21] Smart JP, Patel R, Riley GS. Oxy-fuel combustion of coal and biomass, the effect on radiative and convective heat transfer and burnout. Combust Flame 2010;157:2230-40.

[22] Haykiri-Acma H, Yaman S. Effect of co-combustion on the burnout of lignite/biomass blends: A Turkish case study. Waste Manage 2008;28:2077-84.

[23] Munir S, Nimmo W, Gibbs BM. Shea meal and cotton stalk as potential fuels for co-combustion with coal. Bioresource Technol 2010;101:7614-23.

[24] Andersson K, Normann F, Johnsson F, Leckner B. NO emission during oxy-fuel combustion of lignite. Ind Eng Chem Res 2008;47:1835-45.

[25] Okazaki K, Ando T. $\mathrm{NO}_{\mathrm{x}}$ reduction mechanism in coal combustion with recycled $\mathrm{CO}_{2}$. Energy 1997;22:207-15.

[26] Al-Makhadmeh L, Maier J, Scheffknecht G. Coal pyrolysis and char combustion under oxy-fuel conditions. In: 34th International Technical Conference on Coal Utilization \& Fuel Systems, Clearwater; 2009.

[27] Sun S, Cao H, Chen H, Wang X, Qian J, Wall T. Experimental study of influence of temperature on fuel-N conversion and recycle $\mathrm{NO}$ reduction in oxyfuel combustion. Proc Combust Inst 2011;33:1731-8.

[28] Yoshiie R, Kawamoto T, Hasegawa D, Ueki Y, Naruse I. Gas-phase reaction of $\mathrm{NO}_{\mathrm{x}}$ formation in oxyfuel coal combustion at low temperature. Energy Fuels 2011;25:2481-6.

[29] Jiang X, Huang X, Liu J, Han X. $\mathrm{NO}_{\mathrm{x}}$ emission of fine- and superfine- pulverized coal combustion in $\mathrm{O}_{2} / \mathrm{CO}_{2}$ atmosphere. Energy Fuels 2010;24:6307-13.

[30] Arenillas A, Backreedy RI, Jones JM, Pis JJ, Pourkashanian M, Rubiera F, Williams A. Modelling of NO formation in the combustion of coal blends. Fuel 2002;81:627-36.

[31] Skeen S, Kumfer BM, Axelbaum RL. Nitric Oxide Emissions during Coal and Coal/Biomass Combustion under Air-Fired and Oxy-fuel Conditions. Energy Fuels 2010;24:4144-52.

[32] Liu DC, Zhang CL, Mi B, Shen BK, Feng B. Reduction of $\mathrm{N}_{2} \mathrm{O}$ and NO emissions by co-combustion of coal and biomass. J Inst Energy 2002;75:81-4.

[33] Li S, Wu A, Deng S, Pan W. Effect of co-combustion of chicken litter and coal on emissions in a laboratory-scale fluidized bed combustor. Fuel Process Technol 2008;89:7-12.

[34] Akpulat O, Varol M, Atimtay AT. Effect of freeboard extension on co-combustion of coal and olive cake in a fluidized bed combustor. Bioresource Technol 2010;101:6177-84. 


\section{Figure captions}

Fig. 1. Ignition temperatures of the HVN (a) and SAB (b) coals and their blends with olive waste $(\mathrm{OW})$ under different atmospheres

Fig. 2. Burnout values of the $\mathrm{HVN}$ coal and $\mathrm{HVN}+\mathrm{OW}$ blends under different atmospheres at different fuel equivalence ratios

Fig. 3. Burnout values of the $\mathrm{SAB}$ coal and $\mathrm{SAB}+\mathrm{OW}$ blends under different atmospheres at different fuel equivalence ratios

Fig. 4. Burnout values of the HVN (a) and SAB (b) coals and their blends with olive waste $(\mathrm{OW})$ under different atmospheres at a fuel equivalence ratio of 0.8

Fig. 5. NO emissions of the HVN (a) and SAB (b) coals and their blends with olive waste $(\mathrm{OW})$ under different atmospheres at a fuel equivalence ratio of 0.8 
Table 1. Proximate and ultimate analyses and higher heating value of the fuel samples

\begin{tabular}{|c|c|c|c|}
\hline Sample & HVN & SAB & OW \\
\hline Origin & Spain & $\begin{array}{l}\text { South } \\
\text { Africa }\end{array}$ & Spain \\
\hline Rank & sa & hvb & --- \\
\hline \multicolumn{4}{|l|}{ Proximate Analysis $^{\mathrm{a}}$} \\
\hline Moisture content (wt.\%) & 1.1 & 2.4 & 9.2 \\
\hline Ash (wt.\%, db) & 10.7 & 15.0 & 7.6 \\
\hline V.M. (wt.\%, db) & 9.2 & 29.9 & 71.9 \\
\hline F.C. $(w t . \%, d b)^{b}$ & 80.1 & 55.1 & 20.5 \\
\hline \multicolumn{4}{|l|}{ Ultimate Analysis (wt. $\%$, daf) ${ }^{a}$} \\
\hline $\mathrm{C}$ & 91.7 & 81.5 & 54.3 \\
\hline $\mathrm{H}$ & 3.5 & 5.0 & 6.6 \\
\hline $\mathrm{N}$ & 1.9 & 2.1 & 1.9 \\
\hline S & 1.6 & 0.9 & 0.2 \\
\hline $\mathrm{O}^{\mathrm{b}}$ & 1.3 & 10.5 & 37.0 \\
\hline Higher heating value $(\mathrm{MJ} / \mathrm{kg}, \mathrm{db})$ & 31.8 & 27.8 & 19.9 \\
\hline
\end{tabular}

sa: semi-anthracite; hvb: high-volatile bituminous coal.

$\mathrm{db}$ : dry basis; daf: dry and ash free bases.

${ }^{a}$ The proximate analysis was conducted in a LECO TGA-601, and the ultimate analysis in a LECO CHNS-932.

${ }^{\mathrm{b}}$ Calculated by difference. 


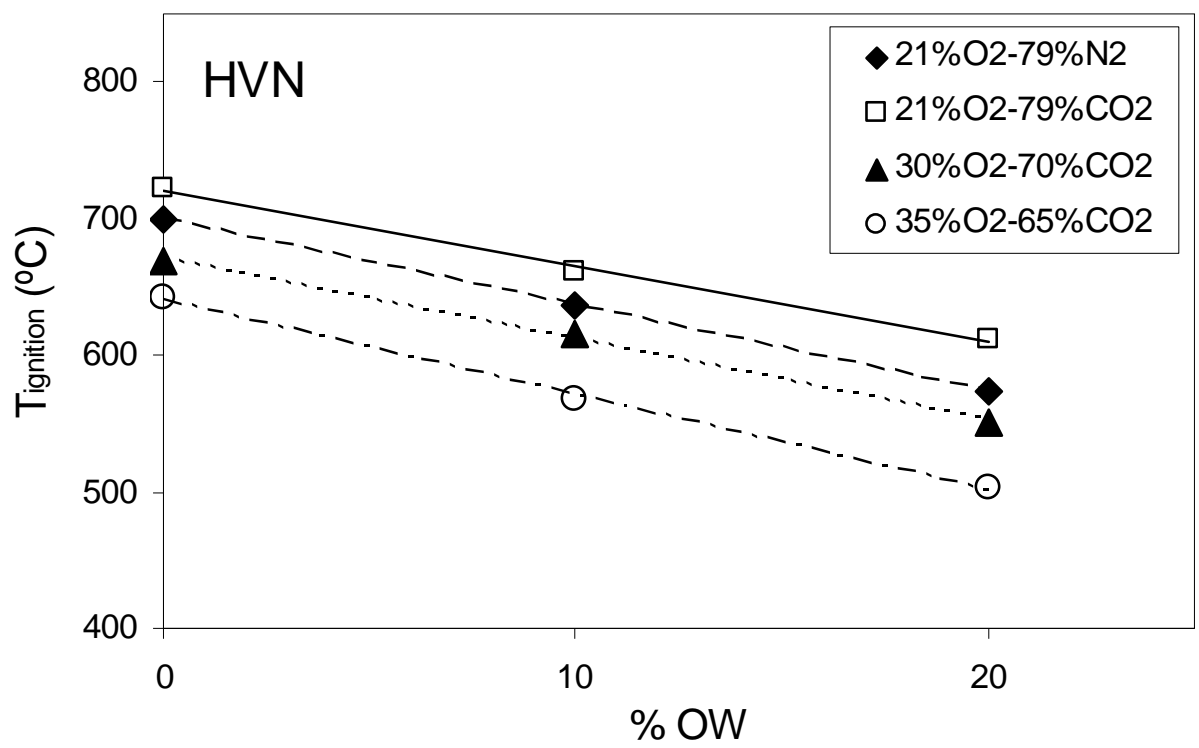

(a)

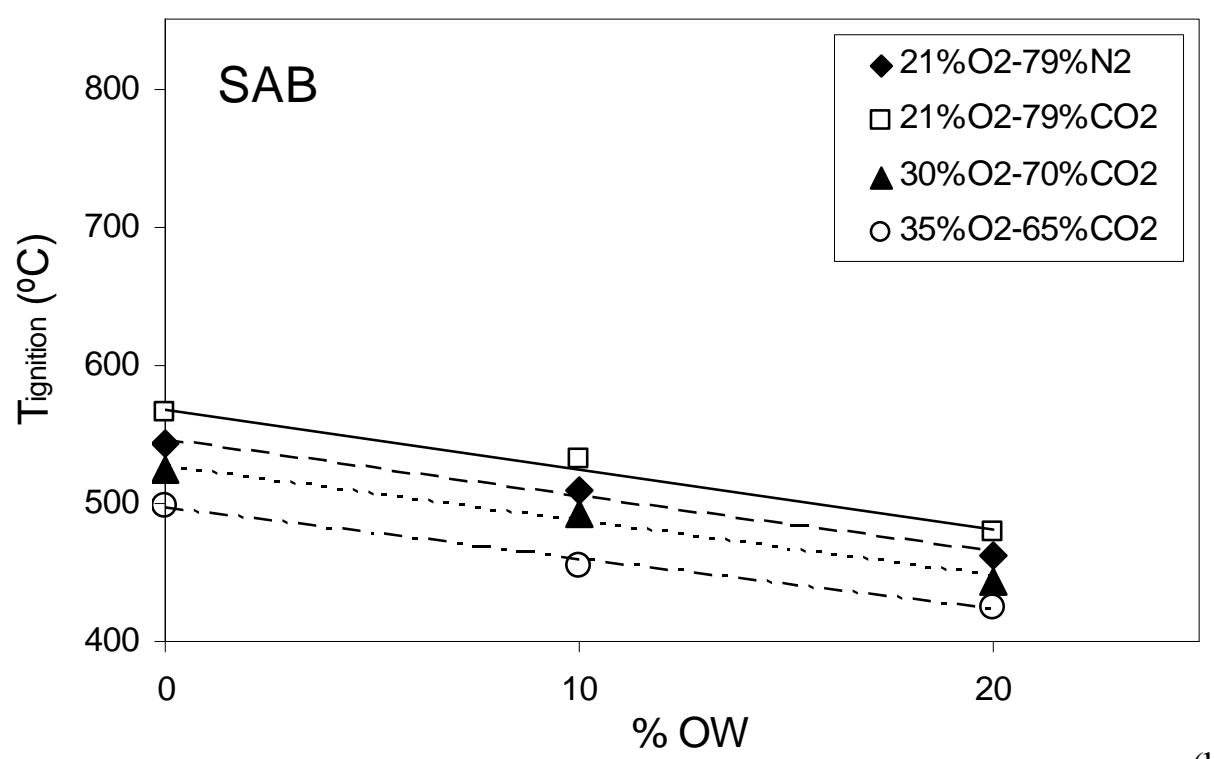

(b)

Fig. 1. 

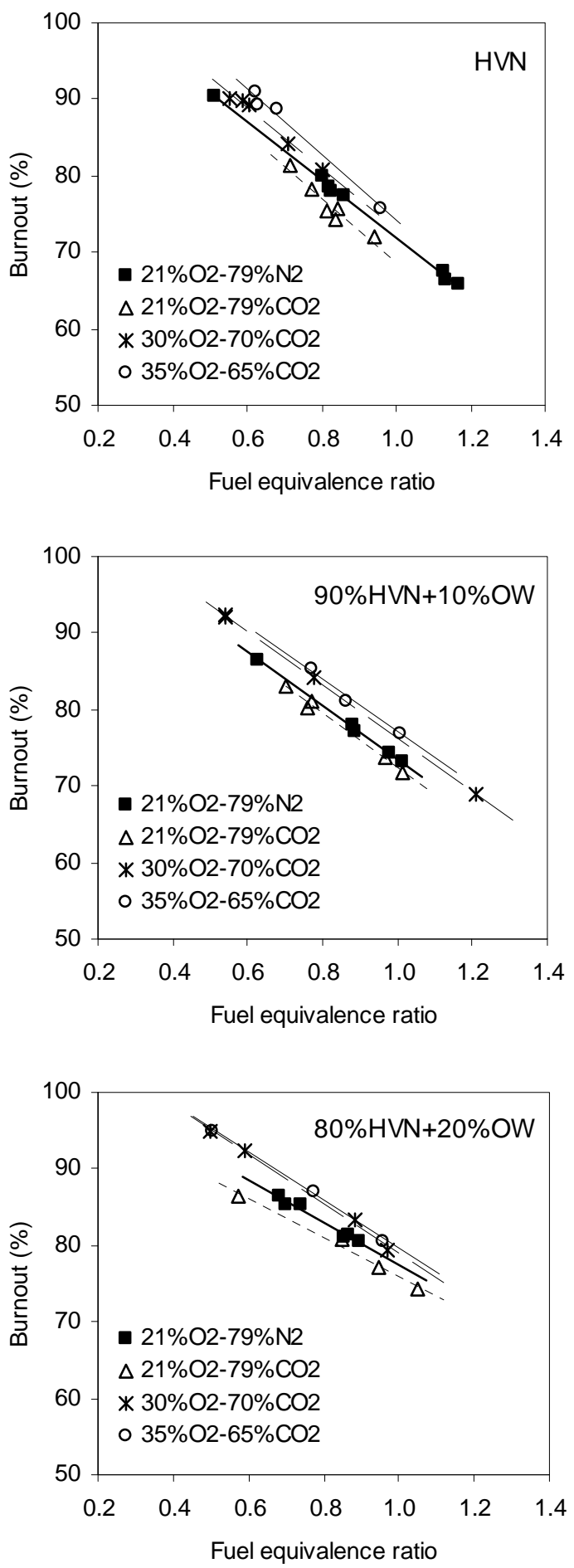

Fig. 2. 

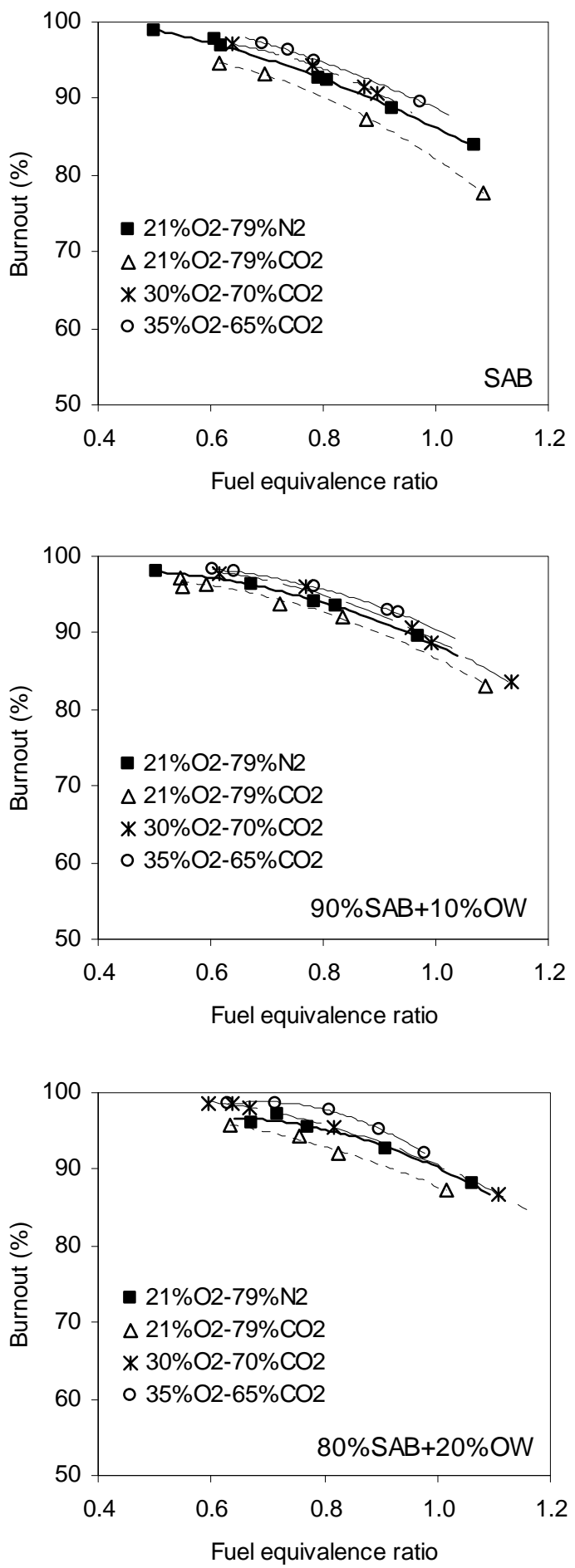

Fig. 3. 


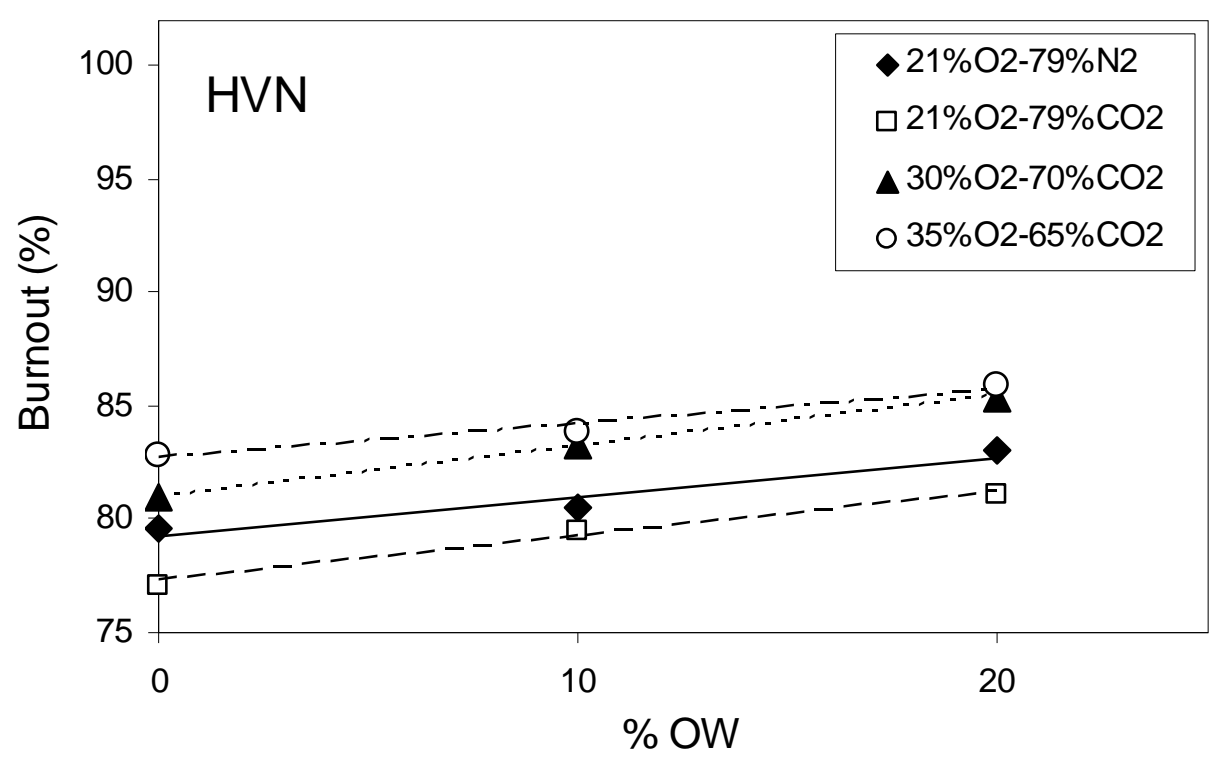

(a)

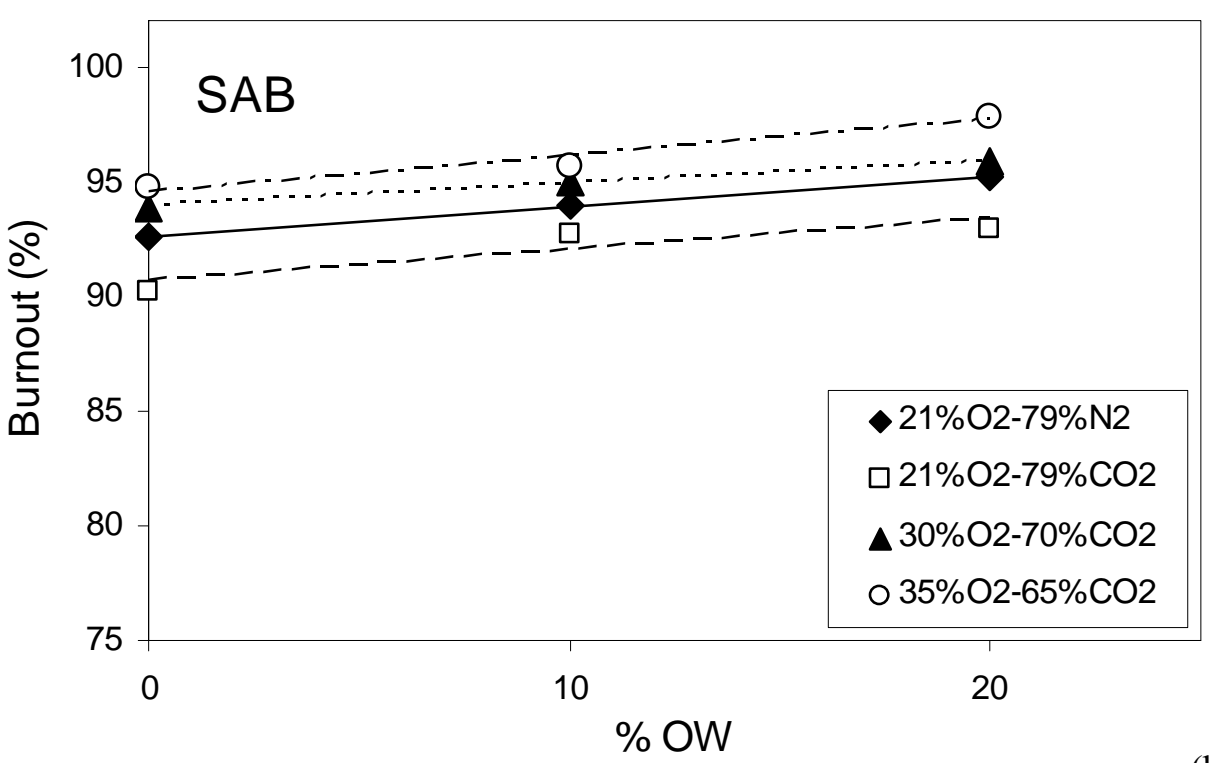

Fig. 4. 


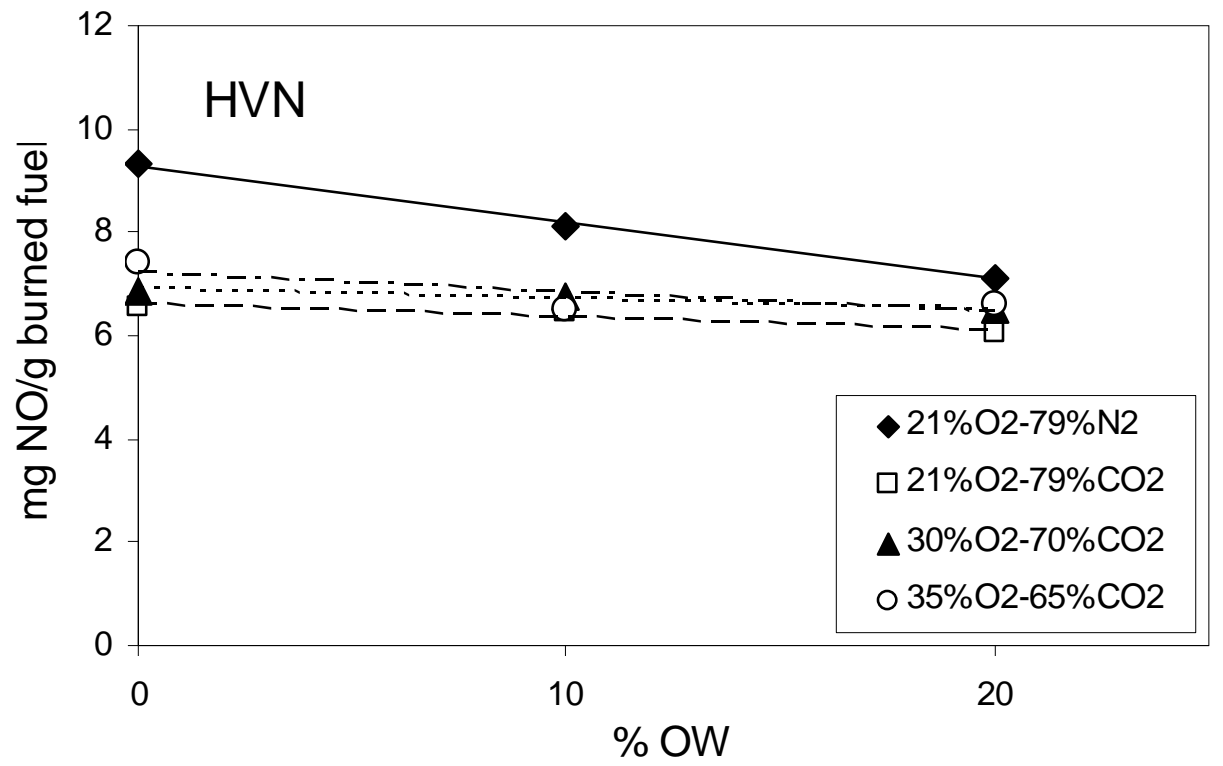

(a)

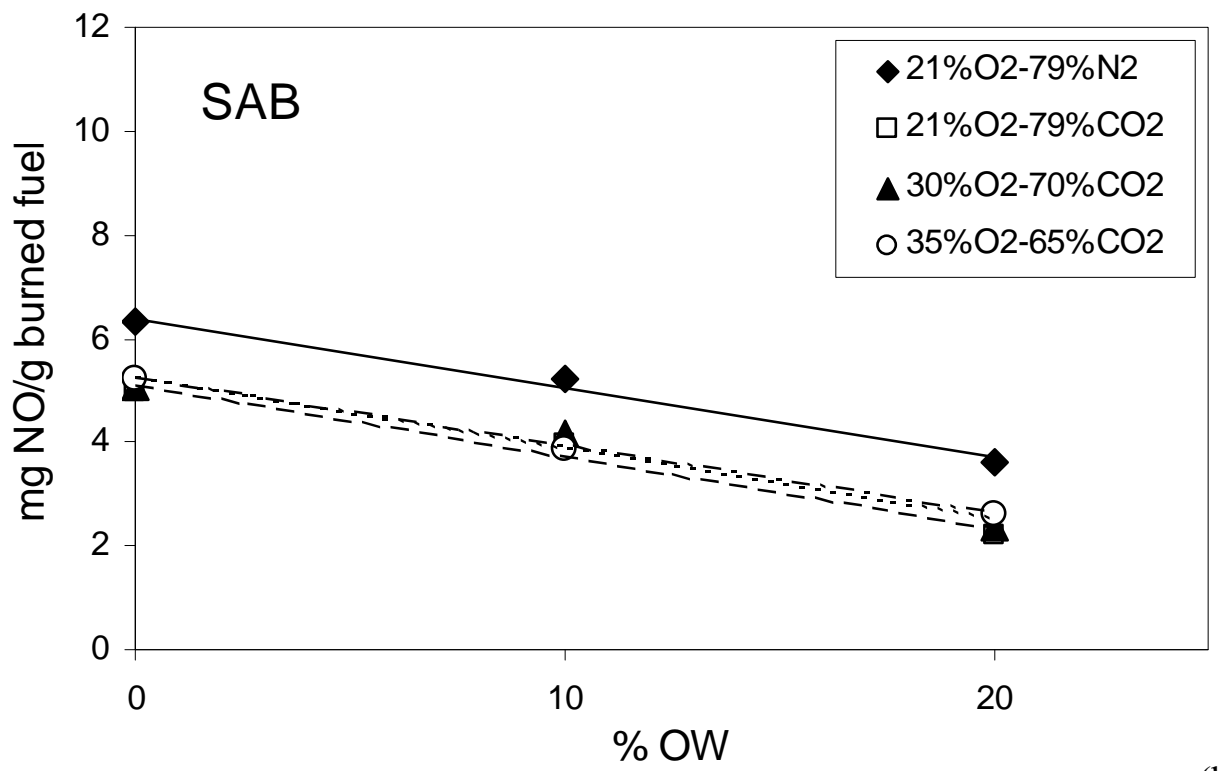

(b)

Fig. 5. 